\title{
Analisis Kinerja Keuangan Pada Koperasi Simpan Pinjam Karya Usaha (KSP-KU) Air Sugihan Kabupaten Ogan Komering llir
}

\author{
Nindi Apriyati ${ }^{1}$, Edduar Hendri ${ }^{2}$, Andri Eko Putra ${ }^{3}$ \\ ${ }^{1}$ Fakultas Ekonomi Universitas PGRI Palembang \\ ${ }^{2}$ Fakultas Ekonomi Universitas PGRI Palembang, hendri edduar@yahoo.com \\ ${ }^{3}$ Fakultas Ekonomi Universitas PGRI Palembang, andriekop@univpgri-palembang.ac.id
}

\begin{abstract}
This study aims to determine the health level of the Air Sugihan Business Savings and Loan Cooperative (KSP-KU), Ogan Komering llir Regency 2016-2018 based on the Regulation of the Minister of Cooperatives and Small and Medium Enterprises of the Republic of Indonesia Number 06 / Per / Dep.6 / IV / 2016 which concerns the aspects of capital, efficiency, liquidity, independence and growth as well as the identity of the cooperative. This research is a descriptive evaluative research type. Data analysis techniques in this study using descriptive analysis. In this study the data were collected through interview and documentation methods. The results showed that the health level of the Air Sugihan Business Savings and Loan Cooperative (KSP-KU), Ogan Komering llir Regency in 2016-2018 was in the fairly healthy category with an average score of 76.82, with details: (1) the capital aspect on average gets a score 6.00 and is in the healthy category; (2) the efficiency aspect averagely scores 6.00 and is in the healthy category; (3) the liquidity aspect scored an average of 3.32 and was under the special supervision category; (4) aspects of independence and growth on average score 2.25 and are in the fairly healthy category; (5) the aspect of cooperative identity on average gets a score of 7.00 and is in the healthy category; (6) the health level of the Air Sugihan Business Savings and Loan Cooperative (KSP-KU) of Ogan Komering llir Regency for 3 years (2016-2018), respectively, obtained a total score of 69.53; 84.38; 76.56 and are in the fairly healthy category.
\end{abstract}

Keywords: Health level, savings and loan cooperatives

\begin{abstract}
ABSTRAK
Penelitian ini bertujuan untuk mengetahui tingkat kesehatan Koperasi Simpan Pinjam Karya Usaha (KSP-KU) Air Sugihan Kabupaten Ogan Komering llir tahun 2016-2018 berdasarkan pada Peraturan Menteri Koperasi dan Usaha Kecil dan Menengah Republik Indonesia Nomor 06/Per/Dep.6/IV/2016 yang menyangkut atas aspek permodalan, efisiensi, likuiditas, kemandirian dan pertumbuhan serta jatidiri koperasi. Penelitian ini merupakan jenis penelitian evaluatif deskriftif. Teknik analisis data dalam penelitian ini menggunakan analisis deskriftif. Dalam penelitian ini data yang dikumpulkan melalui metode wawancara dan dokumentasi. Hasil Penelitian menunjukkan bahwa tingkat kesehatan Koperasi Simpan Pinjam Karya Usaha (KSP-KU) Air Sugihan Kabupaten Ogan Komering llir tahun 2016-2018 berada dalam kategori cukup sehat secara rerata mendapat skor 76,82 dengan rincian: (1) aspek permodalan secara rerata mendapat skor 6,00 dan berada pada kategori sehat; (2) aspek efisiensi secara rerata mendapat skor 6,00 dan berada pada kategori sehat; (3) aspek likuiditas secara rerata mendapat skor 3,32 dan berada pada kategori dalam pengawasan khusus; (4) aspek kemandirian dan pertumbuhan secara rerata mendapat skor 2,25 dan berada pada kategori cukup sehat; (5) aspek jatidiri koperasi secara rerata mendapat skor 7,00 dan berada pada kategori sehat; (6) tingkat kesehatan Koperasi Simpan Pinjam Karya Usaha (KSP-KU) Air Sugihan Kabupaten Ogan Komering llir selama 3 tahun (2016-2018) secara berturut diperoleh total skor sebesar 69,53; 84,38; 76,56 dan berada pada kategori cukup sehat.
\end{abstract}

Kata Kunci: Tingkat kesehatan, Koperasi simpan pinjam 


\section{A. PENDAHULUAN}

Hampir di seluruh dunia mengenal Koperasi. Walaupun per definisi Koperasi dipahami dengan cara yang berbeda-beda, tetapi secara umum Koperasi dikenal sebagai bentuk perusahaan yang unik. la tidak hanya dianggap berbeda dari perusahaan perseorangan yang berbentuk CV, tapi juga dianggap tidak sama dengan perusahaan-perusahaan yang dimiliki oleh sekumpulan orang seperti Firma dan Perseroan Terbatas (PT).

Dalam kegiatan dunia usaha di Indonesia, ada berbagai bentuk badan hukum perusahaan yaitu: Perusahaan Perseorangan; Persekutuan seperti Firma dan Persekutuan Komanditer; Perseroan Terbatas; Badan Usaha Milik Negara; Badan Usaha Milik Daerah; dan Koperasi. Bentuk-Bentuk kegiatan usaha tersebut, selanjutnya dikelompokkan dalam 3 (tiga) sektor, yaitu: Usaha Swasta, Usaha Pemerintah, dan Koperasi.

Koperasi merupakan satu-satunya bentuk usaha yang termuat dalam Pasal 33 ayat (1) Undang-Undang Dasar Negara Republik Indonesia Tahun 1945, ditegaskan bahwa "perekonomian disusun sebagai usaha bersama berdasar atas asas kekeluargaan". Ketentuan tersebut sesuai dengan prinsip Koperasi, karena itu Koperasi mendapat misi untuk berperan nyata dalam meyusun perekonomian yang berdasar atas asas kekeluargaan dan demokrasi ekonomi yang mengutamakan kemakmuran masyarakat bukan kemakmuran orang-seorang. Koperasi tidak hanya merupakan satu-satunya bentuk perusahaan yang secara konstitusional dinyatakan sesuai dengan susunan perekonomian yang hendak dibangun di negeri ini, tapi juga dinyatakan sebagai sokoguru perekonomian nasional.

Definisi Koperasi di Indonesia, dijelaskan dalam Undang-Undang Nomor 25 Tahun 1992 bahwa Koperasi adalah badan usaha yang beranggotakan orang-orang atau badan hukum Koperasi yang melandaskan kegiatannya berdasarkan prinsip Koperasi sekaligus sebagai gerakan ekonomi rakyat yang berdasarkan atas azas kekeluargaan.

Koperasi merupakan lembaga yang sangat dibutuhkan oleh masyarakat pada saat ini dan juga menjadi kegiatan usaha dan pelayanan yang sangat membantu, serta diperlukan oleh para anggota koperasi.

Koperasi Simpan Pinjam Karya Usaha (KSP-KU) Air Sugihan Kabupaten Ogan Komering llir merupakan koperasi yang bergerak dibidang jasa. Kegiatan yang dilakukan di koperasi ini berupa simpan pinjam yang menyediakan dana yang relatif mudah bagi anggotanya dibandingkan dengan prosedur yang harus ditempuh untuk mendapatkan dana dari Bank, pelayanan ini sangat membantu dan diperlukan oleh anggota koperasi dan masyarakat untuk memenuhi kebutuhan kredit.

Koperasi memerlukan alat yang dapat digunakan untuk mengetahui kinerja keuangan koperasi agar manajemen dari pihak koperasi dapat melaksanakan tugas dan kewajibannya dengan baik sesuai dengan tujuan utama koperasi pada umumnya. Salah satu cara untuk mengukur kinerja keuangan pada koperasi yaitu dengan melakukan analisis rasio keuangan.

Rasio menggambarkan suatu hubungan antara suatu jumlah tertentu dengan jumlah yang lain. Dengan mengunakan alat analisis berupa rasio ini akan dapat menjelaskan atau memberi gambaran kepada penganalis tentang baik buruknya keadaan atau posisi keuangan suatu perusahaan. Terutama apabila angka rasio tersebut dibandingkan dengan angka rasio pembanding yang digunakan sebagai standar. 
Berdasarkan Peraturan Menteri Koperasi dan Usaha Kecil dan Menengah Republik Indonesia Nomor 06/Per/Dep.6/IV/2016 tentang Pedoman Penilaian Kesehatan Koperasi Simpan Pinjam dan Unit Simpan Pinjam Koperasi, terdapat tujuh aspek yang dinilai. Aspek tersebut meliputi aspek permodalan, kualitas aktiva produktif, manajemen, efisiensi, likuiditas, kemandirian dan pertumbuhan, serta jati diri koperasi. Dalam hal ini peneliti menggunakan aspek permodalan, efisiensi, likuiditas, kemandirian dan pertumbuhan, serta jati diri koperasi dalam menilai kinerja keuangan Koperasi Simpan Pinjam Karya Usaha (KSP-KU) Air Sugihan Kabupaten Ogan Komering Ilir. Hasil penilaian kesehatan Koperasi akan menunjukkan predikat Koperasi, yaitu predikat sehat, cukup sehat, kurang sehat, tidak sehat atau sangat tidak sehat. Dengan mengetahui kondisi kesehatan Koperasi dapat menjadi bahan pertimbangan untuk mewujudkan kebijakan guna pengembangan Koperasi Simpan Pinjam Karya Usaha (KSP-KU) Air Sugihan Kabupaten Ogan Komering Ilir, sehingga terwujudnya pengelolaan Koperasi yang sehat dan mantap; pengelolaan Koperasi yang efektif, efisien dan profesional; dan terciptanya pelayanan prima kepada anggotanya.

Berdasarkan penelitian terdahulu pada KSP Jogja Sejahtera menunjukkan bahwa tingkat kesehatan KSP Jogja Sejahtera dari segi keuangan menurut Peraturan Menteri Negara Koperasi dan Usaha Kecil dan Menengah Republik Indonesia Nomor 14/Per/M.KUKM/XII/2009 tentang Perubahan atas Peraturan Menteri Negara Koperasi dan Usaha Kecil dan Menengah Nomor 20/Per/M.KUKM/XI/2008 tentang Pedoman Penilaian Kesehatan Koperasi Simpan Pinjam dan Unit Simpan Pinjam Koperasi yaitu pada tahun 2010 diperoleh skor 73,48 dan memiliki predikat "cukup sehat", tahun 2011 diperoleh skor 72,26 dan memiliki predikat "cukup sehat, tahun 2012 diperoleh skor 73,48 dan memiliki predikat "cukup sehat", dan tahun 2013 diperoleh skor 69,82 dan memiliki predikat "cukup sehat". Sedangkan pada KSP Mukti Bina Usaha tingkat kesehatan pada tahun 2011-2013 memperoleh rerata skor sebesar 68,02 dapat dikategorikan dengan predikat "cukup sehat".

\section{B. KAJIAN TEORI}

1) Pengertian Sistem Kinerja Keuangan

Menurut Fahmi (2012:2) bahwa kinerja keuangan merupakan suatu analisis yang dilakukan untuk melihat sejauh mana suatu perusahaan telah melaksanakan dengan menggunakan aturan-aturan pelaksanaan keuangan secara baik dan benar. Seperti dengan membuat suatu laporan keuangan yang telah memenuhi standar dan ketentuan dalam SAK (Standar Akuntansi Keuangan) atau GAAP (General Acepted Principle), dan lainnya.

\section{2) Teknik Analisis Kinerja Keuangan}

Teknik analisis yang biasa digunakan dalam analisis laporan keuangan menurut Kasmir (2012:70-72) adalah sebagai berikut:

$>\quad$ Analisis perbandingan antara laporan keuangan merupakan analisis yang dilakukan dengan membandingkan laporan keuangan lebih dari satu periode.

> Analisis trend atau tendensi merupakan analisis laporan keuangan yang biasanya dinyatakan dalam persentase tertentu. Analisis ini dilakukan dari periode ke periode sehingga akan terlihat apakah perusahaan mengalami perubahan yaitu naik, turun, atau tetap, serta seberapa besar perubahan tersebut yang dihitung dalam persentase. 
Analisis persentase per komponen merupakan analisis yang dilakukan untuk membandingkan antara komponen yang ada dalam suatu laporan keuangan, baik yang ada di neraca maupun laporan laba rugi.

$>\quad$ Analisis sumber dan penggunaan dana merupakan analisis yang dilakukan untuk mengetahui sumber-sumber dana perusahaan dan penggunaan dana dalam suatu periode.

> Analisis sumber dan penggunaan kas merupakan analisis yang digunakan untuk mengetahui sumber-sumber kas perusahaan dan penggunaan uang kas dalam suatu periode.

$>\quad$ Analisis rasio merupakan analisis yang digunakan untuk mengetahui hubungan pos-pos yang ada dalam satu laporan keuangan atau pos-pos antara laporan keuangan neraca dan laporan laba rugi.

$>\quad$ Analisis kredit merupakan analisis yang digunakan untuk menilai layak atau tidaknya suatu kredit dikucurkan oleh lembaga keuangan seperti bank.

$>\quad$ Analisis laba kotor merupakan analisis yang digunakan untuk mengetahui jumlah laba kotor dari periode ke satu periode. Kemudian untuk mengetahui sebab-sebab berubahnya laba kotor tersebut antara periode.

$>\quad$ Analisis titik pulang pokok disebut juga analisis titik impas atau break even point. Tujuan analisis ini adalah untuk mengetahui pada kondisi berapa penjualan produk dilakukan dan perusahaan tidak mengalami kerugian. Kegunaan analisis ini adalah untuk menentukan jumlah keuntungan pada berbagai tingkat penjualan.

\section{3) Tujuan Pengukuran Kinerja Keuangan}

Menurut Munawir (2012:31) menyatakan bahwa tujuan dari pengukuran kinerja keuangan perusahaan adalah:

a. Mengetahui tingkat likuiditas. Likuiditas menunjukkan kemampuan suatu perusahaan untuk memenuhi kewajiban keuangan yang harus segera diselesaikan pada saat ditagih.

b. Mengetahui tingkat solvabilitas. Solvabilitas menunjukkan kemampuan perusahaan untuk memenuhi kewajiban keuangannya apabila perusahaan tersebut dilikuidasi, baik keuangan jangka pendek maupun jangka panjang.

c. Mengetahui tingkat rentabilitas. Rentabilitas atau yang sering disebut dengan profitabilitas menunjukkan kemampuan perusahaan untuk menghasilkan laba selama periode tertentu.

d. Mengetahui tingkat stabilitas. Stabilitas menunjukkan kemampuan perusahaan untuk melakukan usahanya dengan stabil, yang diukur dengan mempertimbangkan kemampuan perusahaan untuk membayar hutanghutangnya serta membayar beban bunga atas hutang-hutangnya tepat pada waktunya.

\section{4) Pengertian Laporan Keuangan}

Menurut Kasmir (2012:7), laporan keuangan adalah laporan yang menunjukkan kondisi keuangan perusahaan pada saat ini atau dalam suatu periode tertentu.

\section{5) Komponen Laporan Keuangan Koperasi}

Dalam Undang-Undang Republik Indonesia No.25 Pasal 35 Tahun 1992 disebutkan bahwa setelah tahun buku koperasi ditutup, paling lambat 1 (satu) bulan sebelum diselenggarakan rapat anggota tahunan, pengurus menyusun laporan tahunan yang memuat sekurang-kurangnya: 
a. Neraca;

b. Perhitungan Hasil Usaha;

c. Catatan Atas Laporan Keuangan;

Dalam pedoman umum akuntansi koperasi, komponen laporan keuangan dilengkapi sesuai dengan Standar Akuntansi Keuangan Entitas Tanpa Akuntabilitas Publik (SAK ETAP), yaitu:

$>$ Laporan Perubahan Ekuitas (Modal);

$>$ Laporan Arus Kas.

\section{6) Pengertian Koperasi}

Koperasi adalah usaha bersama untuk memperbaiki nasib penghidupan ekonomi berdasarkan asas tolong menolong. Semangat tolong menolong tersebut didorong oleh adanya keinginan memberikan jasa kepada kawan berdasarkan seorang buat semua, dan semua buat seorang (Hatta dalam Tanjung, 2016:68).

Menurut Undang-Undang Republik Indonesia No. 25 Pasal 1 Tahun 1992 Koperasi adalah badan usaha yang beranggotakan orang-orang atau badan hukum koperasi yang melandaskan kegiatannya berdasarkan prinsip koperasi sekaligus sebagai gerakan ekonomi rakyat yang berdasarkan atas azas kekeluargaan.

\section{7) Tujuan Koperasi}

Pada Pasal 3 UU No.25 Tahun 1992 yang menyatakan bahwa: 'koperasi bertujuan memajukan kesejahteraan anggota pada khususnya dan masyarakat pada umumnya serta ikut membangun tatanan perekonomian nasional dalam rangka mewujudkan masyarakat yang maju adil dan makmur berlandaskan Pancasila dan UUD 1945.

Berdasarkan Pasal 3 UU No.25 Tahun 1992 ini, tujuan koperasi secara garis besar meliputi:

- Memajukan kesejahteraan anggota dan masyarakat.

- Membangun tatanan ekonomi.

- Terwujudnya masyarakat adil dan makmur.

8) Koperasi Simpan Pinjam

a. Pengertian Koperasi Simpan Pinjam

Berdasarkan Permen KUKM No.14/Per/M.KUKM/XII/2009, dijelaskan bahwa Koperasi Simpan Pinjam merupakan lembaga koperasi yang melakukan kegiatan usaha penghimpunan dan penyaluran dana dari dan untuk anggota, calon anggota, koperasi lain, dan anggotanya, yang perlu dikelola secara profesional sesuai dengan prinsip kehati-hatian dan kesehatan Koperasi Simpan Pinjam, sehingga dapat meningkatkan kepercayaan dan memberikan manfaat yang sebesar-besarnya kepada anggota dan masyarakat di sekitarnya.

b. Pengawasan Koperasi Simpan Pinjam

Menurut Pasal 2 Permen KUKM No.21/Per/M.KUKM/XI/2008 disebutkan bahwa, tujuan pengawasan koperasi simpan pinjam dan unit usaha simpan pinjam koperasi adalah sebagai berikut:

$>\quad$ Mengendalikan KSP dan USP Koperasi agar dalam menjalankan kegiatan usahanya sesuai dengan ketentuan hukum yang berlaku;

$>\quad$ Meningkatkan citra dan kredibilitas KSP dan USP Koperasi sebagai lembaga keuangan yang mampu mengelola dana dari anggota, calon anggota, koperasi lain dan atau anggotanya berdasarkan prinsip koperasi;

$>$ Menjaga dan melindungi aset KSP dan USP Koperasi dari tindakan penyelewengan oleh pihak-pihak yang tidak bertanggungjawab; 
> Meningkatkan transparansi dan akuntabilitas pengelolaan KSP dan USP Koperasi terhadap pihak-pihak yang berkepentingan;

$>\quad$ Mendorong pengelolaan KSP dan USP Koperasi mencapai tujuannya secara efektif dan efisien yaitu meningkatkan pemberdayaan ekonomi anggota.

\section{9) Analisis Kinerja Keuangan Koperasi}

Analisis kinerja keuangan pada koperasi sangat penting dilakukan, apalagi mengingat koperasi perlu mengetahui kinerja keuangannya sebagai pedoman dalam pengambilan keputusan terkait dengan masalah yang dihadapi. Salah satu cara mengukur kinerja keuangan pada koperasi adalah dengan menggunakan rasio keuangan.

Dalam hal ini penilaian kinerja keuangan difokuskan pada koperasi simpan pinjam, sehingga pedoman yang digunakan adalah Peraturan Menteri Koperasi dan Usaha Kecil dan Menengah Republik Indonesia Nomor 06/Per/Dep.6/IV/2016 tentang Pedoman Penilaian Kesehatan Koperasi Simpan Pinjam dan Unit Simpan Pinjam Koperasi. Adapun aspek yang digunakan untuk menilai kinerja keuangan Koperasi Simpan Pinjam (KSP) dan unit Simpan Pinjam (USP) Koperasi adalah sebagai berikut:

\section{a. Permodalan}

Dalam hal ini aspek permodalan dinilai untuk mengetahui informasi mengenai kecukupan modal koperasi dalam mendukung kegiatan operasionalnya.

Berdasarkan Pasal 41 UU No.25 Tahun 1992, modal koperasi terdiri dari modal sendiri dan modal pinjaman.

Modal sendiri dapat berasal dari:
a) Simpanan pokok;
b) Simpanan wajib;
c) Dana cadangan.
d) Hibah.

Modal pinjaman dapat berasal dari:

a) Anggota;

b) Koperasi lainnya dan/atau anggotanya;

c) Bank dan lembaga keuangan lainnya;

d) Penerbitan obligasi dan surat hutang lainnya;

e) Sumber lain yang sah.

Adapun penilaian aspek permodalan didasarkan pada:

\section{Rasio Modal Sendiri terhadap Total Aset}

Rasio ini membandingkan antara modal sendiri dengan total aset koperasi. Rasio ini dihitung dengan rumus sebagai berikut:

$$
\text { Rasio Modal Sendiri terhadap Total Aset }=\frac{\text { Modal Sendiri }}{\text { Total Aset }} \times 100 \%
$$

Untuk Memperoleh rasio antara modal sendiri terhadap total aset ditetapkan sebagai berikut :

- Untuk rasio modal sendiri dengan total aset lebih kecil atau sama dengan $0 \%$ diberikan nilai 0 .

- Untuk setiap kenaikan rasio 4\% mulai dari $0 \%$ nilai ditambah 5 dengan maksimum nilai 100 .

- Untuk Rasio lebih besar dari $60 \%$ sampai rasio $100 \%$ setiap kenaikan rasio $4 \%$ nilai dikurang 5 . 
- Nilai dikalikan bobot sebesar 6\% diperoleh skor permodalan.

Adapun standar penghitungannya adalah sebagai berikut:

Tabel Standar Perhitungan Skor Rasio Modal Sendiri terhadap Total Aset

\begin{tabular}{|c|c|c|c|}
\hline Rasio Modal (\%) & Nilai & Bobot (\%) & Skor \\
\hline 0 & 0 & & 0 \\
\hline $1-20$ & 25 & 6 & 1,50 \\
\hline $21-40$ & 50 & 6 & 3,00 \\
\hline $41-60$ & 100 & 6 & 6,00 \\
\hline $61-80$ & 50 & 6 & 3,00 \\
\hline $81-100$ & 25 & 6 & 1,50 \\
\hline
\end{tabular}

Sumber: Permen KUKM No.06/Per/Dep.6/IV/2016

\section{b. Efisiensi}

Penilaian aspek ini bertujuan untuk menggambarkan sampai seberapa besar KSP atau USP Koperasi mampu memberikan pelayanan yang efisien kepada anggotanya dari penggunaan aset yang dimilikinya. Adapun penilaian aspek efisiensi didasarkan pada:

$>\quad$ Rasio Beban Operasi Anggota terhadap Partisipasi Bruto

Rasio ini dihitung dengan rumus sebagai berikut:

$$
=\frac{\text { Beban Operasi Anggota }}{\text { Partisipasi Bruto }} \times 100 \%
$$

Cara perhitungan rasio beban operasi anggota atas partisipasi bruto ditetapkan sebagai berikut:

1) Untuk rasio sama dengan atau lebih besar dari $100 \%$ diberi nilai 0 dan untuk rasio antara $95 \%$ hingga lebih kecil dari 100\% diberi nilai 50, selanjutnya setiap penurunan rasio sebesar $5 \%$ nilai ditambahkan dengan 25 sampai dengan maksimum nilai 100; dan

2) Nilai dikalikan dengan bobot sebesar $4 \%$ diperoleh skor penilaian.

Tabel Standar Perhitungan Rasio Beban Operasi Anggota terhadap Partisipasi Bruto

\begin{tabular}{|c|c|c|c|}
\hline $\begin{array}{c}\text { Rasio Beban Operasi Anggota } \\
\text { terhadap Partisipasi Bruto (\%) }\end{array}$ & Nilai & $\begin{array}{c}\text { Bobot } \\
(\%)\end{array}$ & Skor \\
\hline$\geq 100$ & 0 & 4 & 1 \\
\hline $95 \leq \times<100$ & 50 & 4 & 2 \\
\hline $90 \leq \times<95$ & 75 & 4 & 3 \\
\hline$<90$ & 100 & 4 & 4 \\
\hline
\end{tabular}

Sumber: Permen KUKM No.06/Per/Dep.6/IV/2016

\section{Rasio Efisiensi Pelayanan}

Rasio ini dihitung dengan rumus sebagai berikut:

$$
=\frac{\text { Biaya Karyawan }}{\text { Volume Pinjaman }} \times 100 \%
$$

Perhitungan rasio efisiensi pelayanan, ditetapkan sebagai berikut:

1) Untuk rasio lebih dari $15 \%$ diberi nilai 0 dan untuk rasio antara $10 \%$ hingga $15 \%$ diberi nilai 50 , selanjutnya setiap penurunan rasio $1 \%$ nilai ditambah 5 sampai dengan maksimum nilai 100 ; dan 
2) Nilai dikalikan dengan bobot sebesar $2 \%$ diperoleh skor penilaian.

Tabel Standar Perhitungan Rasio Efisiensi Pelayanan

\begin{tabular}{|c|c|c|c|}
\hline Rasio Efisiensi Staf (\%) & Nilai & Bobot (\%) & Skor \\
\hline$<5$ & 100 & 2 & 2,0 \\
\hline $5<x<10$ & 75 & 2 & 1,5 \\
\hline $10 \leq x \leq 15$ & 50 & 2 & 1,0 \\
\hline$>15$ & 0 & 2 & 0,0 \\
\hline
\end{tabular}

Sumber: Permen KUKM No.06/Per/Dep.6/IV/2016

\section{c. Likuiditas}

Dalam aspek ini yang ingin diketahui adalah kemampuan KSP dan atau USP Koperasi untuk memenuhi kewajiban jangka pendeknya. Adapun penilaian aspek likuiditas didasarkan pada:

\section{> Rasio Kas dan Bank terhadap Kewajiban Lancar}

Rasio ini dihitung dengan rumus sebagai berikut:

$$
=\frac{\text { Kas }+ \text { Bank }}{\text { Kewajiban Lancar }} \times 100 \%
$$

Pengukuran rasio kas dan bank terhadap kewajiban lancar ditetapkan sebagai berikut:

1) Untuk rasio kas lebih besar dari $10 \%$ hingga $15 \%$ diberi nilai 100 , untuk rasio lebih besar dari $15 \%$ sampai dengan $20 \%$ diberi nilai 50 , untuk rasio lebih kecil sama dengan 10\% diberi nilai 25 sedangkan untuk rasio lebih dari $20 \%$ diberi nilai 25; dan

2) Nilai dikalikan dengan bobot $10 \%$ diperoleh skor penilaian.

Tabel Standar Perhitungan Rasio Kas terhadap Kewajiban Lancar

\begin{tabular}{|c|c|c|c|}
\hline Rasio Kas (\%) & Nilai & Bobot (\%) & Skor \\
\hline$\leq 10$ & 25 & 10 & 2,5 \\
\hline $10<x \leq 15$ & 100 & 10 & 10 \\
\hline $15<x \leq 20$ & 50 & 10 & 5 \\
\hline$>20$ & 25 & 10 & 2,5 \\
\hline
\end{tabular}

Sumber: Permen KUKM No.06/Per/Dep.6/IV/2016

\section{Kemandirian dan Pertumbuhan}

Aspek kemandirian dan pertumbuhan dapat digunakan untuk mengukur seberapa besar kemandirian dan pertumbuhan koperasi apabila dilihat dari kemampuannya memperoleh laba dan operasional pelayanannya. Adapun penilaian aspek kemandirian dan pertumbuhan didasarkan pada:

a) Rasio Rentabilitas Aset

Rasio ini dihitung dengan rumus sebagai berikut:

$$
=\frac{\text { SHU sebelum pajak }}{\text { Total aset }} \times 100 \%
$$

Pengukuran rasio rentabilitas aset ditetapkan sebagai berikut:

- Untuk rasio rentabilitas aset lebih kecil dari 5\% diberi nilai 25 , untuk setiap kenaikan rasio 2,5\% nilai ditambah 25 sampai dengan maksimum 100; dan

- Nilai dikalikan dengan bobot 3\% diperoleh skor penilaian. 
Tabel Standar Perhitungan Skor untuk Rasio Rentabilitas Aset

\begin{tabular}{|c|c|c|c|}
\hline Rasio Rentabilitas Aset (\%) & Nilai & Bobot (\%) & Skor \\
\hline$<5$ & 25 & 3 & 0,75 \\
\hline $5 \leq x<7,5$ & 50 & 3 & 1,50 \\
\hline $7,5 \leq \times<10$ & 75 & 3 & 2,25 \\
\hline 10 & 100 & 3 & 3,00 \\
\hline
\end{tabular}

Sumber: Permen KUKM No.06/Per/Dep.6/IV/2016

\section{Jati Diri Koperasi}

Penilaian aspek jatidiri koperasi dimaksudkan untuk mengukur keberhasilan koperasi dalam mencapai tujuannya, yaitu mempromosikan ekonomi anggota. Adapun rasio yang digunakan adalah sebagai berikut:

a) Rasio Partisipasi Bruto

Rasio partisipasi bruto adalah tingkat kemampuan koperasi dalam melayani anggota, semakin tinggi/besar persentasenya semakin baik.

Rasio ini dihitung dengan menggunakan rumus sebagai berikut:

$$
=\frac{\text { Partisipasi Bruto }}{\text { Partisipasi Bruto }+ \text { Pendapatan }} \times 100 \%
$$

Perhitungan rasio partisipasi bruto ditetapkan sebagai berikut:

- Untuk rasio lebih kecil dari 25\% diberi nilai 25 dan untuk setiap kenaikan rasio 25\% nilai ditambah dengan 25 sampai dengan rasio lebih besar dari $75 \%$ nilai maksimum 100 .

- Nilai dikalikan dengan bobot 7\% diperoleh skor penilaian.

Tabel Standar Perhitungan Rasio Partisipasi Bruto

\begin{tabular}{|c|c|c|c|}
\hline Rasio Partisipasi Bruto (\%) & Nilai & Bobot (\%) & Skor \\
\hline$<25$ & 25 & 7 & 1,75 \\
\hline $25 \leq \times<50$ & 50 & 7 & 3,50 \\
\hline $50 \leq x<75$ & 75 & 7 & 5,25 \\
\hline$\geq 75$ & 100 & 7 & 7 \\
\hline
\end{tabular}

Sumber: Permen KUKM No.06/Per/Dep.6/IV/2016

10) Penelitian Terdahulu

Tabel Tabel Penelitian Terdahulu yang Relevan

\begin{tabular}{|c|c|c|c|c|}
\hline No & Nama & Judul & $\begin{array}{c}\text { Teknik } \\
\text { Analisis Data }\end{array}$ & Hasil \\
\hline 1 & $\begin{array}{c}\text { Sri Aryani } \\
2014\end{array}$ & $\begin{array}{lr}\text { Analisis } & \text { Kinerja } \\
\text { Keuangan } & \text { Pada } \\
\text { Koperasi } & \text { Pegawai } \\
\text { Mufakat } & \text { Pangkalan } \\
\text { Balai } & \text { Kabupaten } \\
\text { Banyuasin } & \end{array}$ & $\begin{array}{l}\text { Analisis } \\
\text { deskriftif } \\
\text { kuantitatif }\end{array}$ & $\begin{array}{l}\text { Hasil perhitungan analisis } \\
\text { rasio keuangan Koperasi } \\
\text { pegawai Mufakat di } \\
\text { Pangkalan Balai, pada tahun } \\
2011 \text { sampai dengan } 2013 \\
\text { secara keseluruhan dapat } \\
\text { dikatakan cukup baik. }\end{array}$ \\
\hline 2 & $\begin{array}{l}\text { Oktavian } \\
\text { Nugroho } \\
2015\end{array}$ & $\begin{array}{lr}\text { Analisis } & \text { Kinerja } \\
\text { Keuangan } & \text { Koperasi } \\
\text { Pada } & \text { Koperasi } \\
\text { Beringin Palembang }\end{array}$ & $\begin{array}{l}\text { Analisis } \\
\text { deskriftif } \\
\text { kualitatif }\end{array}$ & \begin{tabular}{lrr} 
Hasil & penelitian & pada \\
Koperasi Beringin Palembang & \\
dari tahun 2012 & sampai \\
dengan 2014 & secara \\
keseluruhan dapat & dikatakan \\
\multicolumn{3}{l}{ sudah sangat baik. }
\end{tabular} \\
\hline
\end{tabular}




\begin{tabular}{|c|c|c|c|c|}
\hline 3 & $\begin{array}{c}\text { Andi } \\
\text { Apriadi } \\
2014\end{array}$ & $\begin{array}{lr}\text { Analisis } & \text { Kinerja } \\
\text { Keuangan } & \text { Koperasi } \\
\text { Berdasarkan } & \\
\text { Peraturan } & \text { Menteri } \\
\text { Negara Koperasi dan } \\
\text { Usaha Kecil dan } \\
\text { Menengah } & \text { Republik } \\
\text { Indonesia } & \text { Nomor } \\
\text { 14/Per/M.KUKM/XII/20 } \\
09\end{array}$ & $\begin{array}{l}\text { Analisis } \\
\text { Statistika } \\
\text { Deskriptif }\end{array}$ & $\begin{array}{lr}\text { Hasil penelitian } & \text { tingkat } \\
\text { kesehatan pada Koperasi } \\
\text { Simpan Pinjam (KSP) Jogja } \\
\text { Sejahtera dari segi keuangan } \\
\text { pada tahun } 2010 \\
\text { memperoleh predikat "cukup } \\
\text { sehat", tahun } 2011 \\
\text { berpredikat "cukup sehat", } \\
\text { tahun } 2012 \text { berpredikat } \\
\text { "cukup sehat", dan tahun } \\
2013 \text { berpredikat "cukup } \\
\text { sehat". }\end{array}$ \\
\hline 4 & $\begin{array}{c}\text { Alfi } \\
\text { Rohmani } \\
\text { ng Tyas } \\
2014\end{array}$ & $\begin{array}{l}\text { Analisis } \quad \text { Tingkat } \\
\text { Kesehatan Koperasi } \\
\text { Simpan Pinjam Mukti } \\
\text { Bina Usaha Kelurahan } \\
\text { Muktisari Kota Banjar } \\
\text { Jawa Barat Tahun } \\
\text { 2011-2013 }\end{array}$ & $\begin{array}{l}\text { Analisis } \\
\text { Deskriftif }\end{array}$ & $\begin{array}{l}\text { Hasil penelitian menunjukkan } \\
\text { bahwa tingkat kesehatan } \\
\text { KSP Mukti Bina Usaha tahun } \\
2011-2013 \text { berada dalam } \\
\text { kategori cukup sehat. }\end{array}$ \\
\hline
\end{tabular}

\section{METODE PENELITIAN}

\section{1) Objek/ Lokasi Penelitian}

Objek penelitian ini adalah Koperasi Simpan Pinjam Karya Usaha (KSP-KU) Air Sugihan Kabupaten Ogan Komering llir.

\section{2) Variabel Penelitian}

Menurut Sugiono (2018:38) Variabel penelitian adalah suatu atribut atau sifat atau nilai dari orang, obyek atau kegiatan yang mempunyai variabel tertentu yang ditetapkan oleh peneliti untuk dipelajari dan ditarik kesimpulannya.

\section{3) Definisi Operasional Variabel}

Operasional variabel adalah penjelasan dari variabel yang telah dipilih oleh peneliti. Operasional variabel meliputi variabel, definisi dan indikator yang dapat dilihat pada tabel dibawah ini:

Tabel Definisi Operasional Variabel

\begin{tabular}{|l|l|l|l|}
\hline Variabel & \multicolumn{2}{|c|}{ Definisi } & \multicolumn{1}{|c|}{ Indikator } \\
\hline Kinerja & Kinerja keuangan merupakan suatu & 1. Permodalan \\
Keuangan & analisis yang dilakukan untuk melihat & 2. Efisiensi \\
& sejauh mana suatu perusahaan telah & 3. Likuiditas \\
& melaksanakan dengan menggunakan & 4. Kemandirian dan \\
& aturan-aturan pelaksanaan keuangan & pertumbuhan \\
& secara baik dan benar. Fahmi (2012) & 5. Jati diri koperasi \\
\hline
\end{tabular}

\section{4) Populasi}

Menurut Sugiyono (2018:80) Populasi adalah wilayah generalisasi yang terdiri dari atas objek dan subjek yang mempunyai kualitas dan karakteristik tertentu yang ditetapkan oleh peneliti untuk dipelajari dan kemudian ditarik kesimpulannya. Adapun Populasi dalam penelitian ini adalah laporan keuangan Koperasi Karya Usaha (KSP$\mathrm{KU})$ Air Sugihan Kabupaten Ogan Komering llir. 


\section{5) Sampel}

Menurut Sugiyono (2018:81) Sampel adalah bagian dari jumlah karakteristik yang dimiliki oleh populasi tersebut. Sampel dalam penelitian ini adalah berupa laporan keuangan Koperasi Karya Usaha (KSP-KU) Air Sugihan Kabupaten Ogan Komering llir pada tahun 2016-2018.

\section{6) Sumber Data}

Menurut Sugiyono (2018:190), beberapa jenis dan sumber data dalam suatu penelitian adalah sebagai berikut:

$>$ Data Primer

Data primer adalah data yang dikumpulkan sendiri oleh perorangan/suatu organisasi secara langsung dari objek yang diteliti dan untuk kepentingan studi yang bersangkutan yang dapat berupa interview dan observasi.

$>$ Data Sekunder

Data sekunder adalah data yang diperoleh dan dikumpulkan dengan melakukan studi kepustakaan terhadap dokumen-dokumen grafis yang berhubungan.

Sumber data dalam penelitian ini adalah data sekunder.

\section{7) Metode Pengumpulan Data}

Beberapa metode pengumpulan data menurut Sugiyono (2018:199) pada suatu penelitian yaitu :

$>$ Dokumentasi

Dokumentasi adalah catatan peristiwa yang sudah berlalu. Dokumen bisa berbentuk tulisan, gambar atau karya monumental seseorang.

$>$ Wawancara

Wawancara merupakan teknik pengumpulan data apabila peneliti ingin melakukan studi pendahuluan untuk menemukan permasalahan yang harus diteliti, dan juga apabila peneliti ingin mengetaui hal-hal dari responden yang lebih mendalam dan jumlah trespondennya sedikit/kecil.

Dalam penelitian ini penulis menggunakan teknik pengumpulan data yang berupa dokumentasi.

\section{8) Teknik Analisis Data}

Menurut Sugiyono (2018:140) Teknik analisis data digunakan untuk menjawab rumusan masalah atau menguji hipotesis. Teknik analisis data yang digunakan adalah analisis deskriftif dengan berpedoman pada Peraturan Menteri Koperasi dan Usaha Kecil dan Menengah Republik Indonesia Nomor 06/Per/Dep.6/IV/2016 dengan rincian sebagai berikut :

a) Penilaian Aspek dan Komponen Kesehatan KSP

Penilaian aspek-aspek kesehatan koperasi diberikan bobot sesuai dengan besarnya pengaruh terhadap kesehatan koperasi. Penilaian aspek dilakukan dengan menggunakan nilai yang dinyatakan dalam angka 0 sampai dengan 100 . Bobot penilaian terhadap aspek dan komponen tersebut ditetapkan sebagai berikut:

Tabel Aspek, Komponen, dan Penilaian Kesehatan KSP

\begin{tabular}{|c|c|c|c|c|}
\hline No & Aspek & Aspek & $\begin{array}{c}\text { Bobot } \\
\text { Penilaian }\end{array}$ \\
\hline 1. & Permodalan & & 6 \\
\hline & \multicolumn{1}{|c|}{ a. Rasio Modal Sendiri terhadap Total Aset } & 6 & \\
\hline
\end{tabular}




\begin{tabular}{|c|l|l|c|c|}
\hline 2. & Efisiensi & & 6 \\
\hline & & $\begin{array}{l}\text { a. Rasio Beban Operasi Anggota terhadap } \\
\text { Partisipasi Bruto }\end{array}$ & 4 & \\
\cline { 3 - 5 } & b. Rasio Efisiensi Pelayanan & 2 & \\
\hline 3. & Likuiditas & & 10 \\
\hline & \multicolumn{2}{|l|}{ a. Rasio Kas } & 10 & 3 \\
\hline 4. & Kemandirian dan Pertumbuhan & 3 & \\
\hline & a. Rentabilitas Aset & & 7 \\
\hline 5. & Jatidiri Koperasi & 7 & \\
\hline & a. Rasio Partisipasi Bruto & & $\mathbf{3 2}$ \\
\hline
\end{tabular}

Sumber: Permen KUKM No.06/Per/Dep.6/IV/2016

Setelah masing-masing skor rasio keuangan diketahui kemudian menghitung bobot aspek keuangannya. Dalam penelitian ini hanya menghitung rasio dari 5 (lima) aspek saja yaitu aspek permodalan, efisiensi, likuiditas, kemandirian dan pertumbuhan, serta jatidiri koperasi. Sedangkan dalam Permen KUKM No.06/Per/Dep.6/IV/2016 terdapat 7 (tujuh) aspek yang dinilai yaitu aspek permodalan, kualitas aktiva produktif, manajemen, efisiensi, likuiditas, kemandirian dan pertumbuhan, dan jatidiri koperasi. Oleh karena itu, perlu adanya konversi untuk menyetarakan penilaiannya, sehingga dapat dimasukkan ke dalam kategori penetapan kinerja keuangan koperasi. Adapun cara mengkonversikan skor yang dihasilkan adalah sebagai berikut:

$$
=\frac{\text { Skor Hasil Perhitungan }}{\text { Jumlah Skor Keseluruhan (Lima Aspek) }} \times 100
$$

b) Penilaian Tingkat Kesehatan KSP

Perincian mengenai tata cara penilaian kesehatan KSP menggunakan pedoman sebagai berikut:

Tabel Penetapan Predikat Tingkat Kesehatan Koperasi

\begin{tabular}{|c|l|}
\hline SKOR & \multicolumn{1}{|c|}{ PREDIKAT } \\
\hline $80.00<x<100$ & SEHAT \\
\hline $66.00<x<80.00$ & CUKUP SEHAT \\
\hline $51.00<x<66.00$ & DALAM PENGAWASAN \\
\hline$<51.00$ & DALAM PENGAWASAN KHUSUS \\
\hline
\end{tabular}

Sumber: Permen KUKM No.06/Per/Dep.6/IV/2016

D. HASIL PENELITIAN

a) Analisis Penilaian Kinerja Keuangan KSP-KU

Analisis data yang digunakan dalam penelitian ini menggunakan analisis deskriftif dengan berpedoman pada Peraturan Menteri Koperasi dan Usaha Kecil dan Menengah Republik Indonesia Nomor 06/Per/Dep.6/IV/2016. Aspek yang dinilai yaitu permodalan, efisiensi, likuiditas, kemandirian dan pertumbuhan, serta jati diri koperasi. Hasil analisis akan memberikan gambaran mengenai tingkat kesehatan keuangan pada Koperasi Karya Usaha (KSP-KU) Air Sugihan Kabupaten Ogan Komering llir. Adapun perhitungan rasio masing-masing aspek penilaian kesehatan koperasi akan diuraikan sebagai berikut: 


\section{Permodalan}

Aspek permodalan dinilai untuk mengetahui informasi mengenai kecukupan modal KSP-KU dalam mendukung kegiatan operasionalnya.

1. Rasio Modal Sendiri terhadap Total Aset

Rasio ini digunakan untuk mengetahui tingkat kemampuan modal sendiri KSP$\mathrm{KU}$ dalam mendukung pendanaan terhadap total aset yang dimilkinya. Rasio ini dihitung dengan rumus sebagai berikut:

$$
\begin{aligned}
& \frac{\text { Modal Sendiri }}{\text { Total Aset }} \times 100 \% \\
= & \frac{R p 9.106 .308 .919,00}{R p 18.616 .581 .687,00} \times 100 \%=48,92 \% \\
= & \frac{R p 10.732 .709 .719,00}{R p 18.286 .996 .245,00} \times 100 \%=58,69 \% \\
= & \frac{R p 8.952 .304 .343,00}{R p 16.150 .557 .577,00} \times 100 \%=55,43 \%
\end{aligned}
$$

Tahun 2016

Tahun 2017

Tahun 2018

Rasio modal sendiri terhadap total aset KSP-KU tahun 2016-2018 diperoleh dari hasil perhitungan pada data keuangan koperasi, disajikan dalam tabel berikut:

Tabel Rasio Modal Sendiri terhadap Total Aset Tahun 2016-2018

\begin{tabular}{|c|rr|rr|c|}
\hline Tahun & \multicolumn{2}{|c|}{ Modal Sendiri } & \multicolumn{2}{c|}{ Total Aset } & $\begin{array}{c}\text { Rasio } \\
\text { (\%) }\end{array}$ \\
\hline 2016 & $\mathrm{Rp}$ & $9.106 .308 .919,00$ & $\mathrm{Rp}$ & $18.616 .581 .687,00$ & 48,92 \\
\hline 2017 & $\mathrm{Rp}$ & $10.732 .709 .719,00$ & $\mathrm{Rp}$ & $18.286 .996 .245,00$ & 58,69 \\
\hline 2018 & $\mathrm{Rp}$ & $8.952 .304 .343,00$ & $\mathrm{Rp}$ & $16.150 .557 .577,00$ & 55,43 \\
\hline
\end{tabular}

Sumber: Laporan Keuangan KSP-KU Tahun 2016-2018

Berdasarkan perhitungan rasio pada tabel, kemudian dilakukan penskoran untuk hasil rasio tersebut yang disajikan dalam tabel berikut ini:

Tabel Penskoran Rasio Modal Sendiri terhadap Total Aset Tahun 2016-2018

\begin{tabular}{|c|c|c|c|c|}
\hline Tahun & Rasio(\%) & Nilai (a) & Bobot (\%) (b) & Skor (a) $^{\star}(\mathbf{b})$ \\
\hline 2016 & 48,92 & 100 & 6 & 6,00 \\
\hline 2017 & 58,69 & 100 & 6 & 6,00 \\
\hline 2018 & 55,43 & 100 & 6 & 6,00 \\
\hline
\end{tabular}

Sumber: Data sekunder yang telah diolah

Berdasarkan perhitungan diatas, dapat diketahui bahwa rasio modal sendiri terhadap total aset KSP-KU dari tahun 2016 sampai tahun 2017 mengalami kenaikan, dan dari tahun 2017 sampai tahun 2018 mengalami penurunan.

\section{Efisiensi}

Penilaian aspek efisiensi bertujuan mengukur tingkat kemampuan KSP-KU dalam memberikan pelayanan kepada anggotanya dengan aset yang dimilikinya.

1. Rasio Beban Operasi Anggota terhadap Partisipasi Bruto Rasio ini digunakan untuk mengetahui kemampuan partisipasi bruto KSP-KU dalam menutup kemungkinan kerugian akibat besarnya beban operasi anggota. Rasio ini dihitung dengan rumus sebagai berikut: 
Tahun 2016

$$
=\frac{\text { Beban Operasi Anggota }}{\text { Partisipasi Bruto }} \times 100 \%
$$

Tahun 2017

Tahun 2018

$$
\begin{aligned}
& =\frac{R p 2.682 .403 .496,00}{R p 3.106 .007 .200,00} \times 100 \%=86,36 \% \\
& =\frac{R p 2.366 .585 .825,00}{R p 4.577 .392 .800,00} \times 100 \%=51,70 \% \\
& =\frac{R p 1.904 .872 .022,00}{R p 4.369 .245 .000,00} \times 100 \%=43,60 \%
\end{aligned}
$$

Rasio beban operasi anggota terhadap partisipasi bruto KSP-KU tahun 20162018 diperoleh hasil perhitungan pada data keuangan koperasi, disajikan dalam tabel berikut:

Tabel Rasio Beban Operasi Anggota terhadap Partisipasi Bruto

Tahun 2016-2018

\begin{tabular}{|c|cr|cr|c|}
\hline Tahun & \multicolumn{2}{|c|}{ Beban Operasi Anggota } & \multicolumn{2}{|c|}{ Partisipasi Bruto } & Rasio (\%) \\
\hline 2016 & $\mathrm{Rp}$ & $2.682 .403 .496,00$ & $\mathrm{Rp}$ & $3.106 .007 .200,00$ & 86,36 \\
\hline 2017 & $\mathrm{Rp}$ & $2.366 .585 .825,00$ & $\mathrm{Rp}$ & $4.577 .392 .800,00$ & 51,70 \\
\hline 2018 & $\mathrm{Rp}$ & $1.904 .872 .022,00$ & $\mathrm{Rp}$ & $4.369 .245 .000,00$ & 43,60 \\
\hline
\end{tabular}

Sumber: Laporan Keuangan KSP-KU tahun 2016-2018

Berdasarkan perhitungan rasio pada tabel, kemudian dilakukan penskoran untuk hasil rasio tersebut yang disajikan dalam tabel berikut ini:

\section{Tabel Penskoran Rasio Beban Operasi Anggota terhadap Partisipasi Bruto} Tahun 2016-2018

\begin{tabular}{|c|c|c|c|c|}
\hline Tahun & Rasio(\%) & Nilai (a) & Bobot (\%) (b) & ${\text { Skor (a) }{ }^{\star}(\mathbf{b})}$ \\
\hline 2016 & 86,36 & 100 & 4 & 4,00 \\
\hline 2017 & 51,70 & 100 & 4 & 4,00 \\
\hline 2018 & 43,60 & 100 & 4 & 4,00 \\
\hline
\end{tabular}

\section{Sumber: Data sekunder yang telah diolah}

Berdasarkan perhitungan diatas, dapat diketahui bahwa rasio beban operasi anggota terhadap partisipasi bruto KSP-KU dari tahun 2016 sampai tahun 2017 mengalami penurunan, dan dari tahun 2017 sampai tahun 2018 juga mengalami penurunan.

\section{Rasio Efisiensi Pelayanan}

Rasio ini digunakan untuk mengetahui tingkat kemampuan volume pinjaman yang diberikan KSP-KU dalam menutup kemungkinan kerugian akibat besarnya beban karyawan koperasi. Rasio ini dihitung dengan rumus sebagai berikut:

$$
=\frac{\text { Biaya Karyawan }}{V \text { 摩lume Pinjaman }} \times 100 \%
$$

Tahun 2016 $=\frac{R p 134.479 .791,00}{R p 14.382 .475 .000,00} \times 100 \%=0,94 \%$

Tahun 2017 $=\frac{R p 158.215 .000,00}{R p 12.705 .610 .000,00} \times 100 \%=1,25 \%$

Tahun 2018 $=\frac{R p 181.017 .000,00}{R p 13.260 .290 .000,00} \times 100 \%=1,37 \%$

Rasio efisiensi pelayanan KSP-KU tahun 2016-2018 diperoleh hasil perhitungan pada data keuangan koperasi, disajikan dalam tabel berikut: 
Tabel Rasio Efisiensi Pelayanan Tahun 2016-2018

\begin{tabular}{|c|c|c|c|c|c|}
\hline Tahun & \multicolumn{2}{|c|}{ Biaya Karyawan } & \multicolumn{2}{|c|}{ Volume Pinjaman } & Rasio (\%) \\
\hline 2016 & $\mathrm{Rp}$ & $134.479 .791,00$ & $\mathrm{Rp}$ & $14.382 .475 .000,00$ & 0,94 \\
\hline 2017 & $\mathrm{Rp}$ & $158.215 .000,00$ & $\mathrm{Rp}$ & $12.705 .610 .000,00$ & 1,25 \\
\hline 2018 & $\mathrm{Rp}$ & $181.017 .000,00$ & $\mathrm{Rp}$ & $13.260 .290 .000,00$ & 1,37 \\
\hline
\end{tabular}

Sumber: Laporan Keunagan KSP-KU tahun 2016-2018

Berdasarkan perhitungan rasio pada tabel, kemudian dilakukan penskoran untuk hasil rasio tersebut yang disajikan dalam tabel berikut ini:

Tabel Penskoran Rasio Efisiensi Pelayanan Tahun 2016-2018

\begin{tabular}{|c|c|c|c|c|}
\hline Tahun & Rasio(\%) & Nilai (a) & Bobot (\%) (b) & Skor (a) \\
\hline 2016 & 0,94 & 100 & 2 & 2,00 \\
\hline 2017 & 1,25 & 100 & 2 & 2,00 \\
\hline 2018 & 1,37 & 100 & 2 & 2,00 \\
\hline
\end{tabular}

Sumber: Data sekunder yang telah diolah

Berdasarkan perhitungan diatas, dapat diketahui bahwa rasio efisiensi pelayanan KSP-KU dari tahun 2016 sampai tahun 2017 mengalami kenaikan, dan dari tahun 2017 sampai tahun 2018 juga mengalami kenaikan.

\section{$>\quad$ Likuiditas}

Penilaian aspek likuiditas bertujuan untuk mengukur tingkat kemampuan KSP$\mathrm{KU}$ dalam memenuhi kewajiban jangka pendek.

1. Rasio Kas

Rasio ini digunakan untuk mengetahui tingkat kemampuan KSP-KU dalam membayar hutang jangka pendeknya dengan menggunakan kas dan bank yang dimiliki koperasi. Rasio ini dihitung dengan rumus sebagai berikut:

$$
=\frac{\text { Kas }+ \text { Bank }}{\text { Kewajiban Lancar }} \times 100 \%
$$

Tahun 2016 $=\frac{R p 135.227 .074,00}{R p 9.510 .272 .768,00} \times 100 \%=1,42 \%$

Tahun 2017 $=\frac{R p 1.486 .511 .479,00}{R p 7.554 .286 .526,00} \times 100 \%=19,68 \%$

Tahun $2018=\frac{R p 203.863 .445,00}{R p 7.198 .253 .234,00} \times 100 \%=2,83 \%$

Rasio kas dan bank terhadap kewajiban lancar KSP-KU tahun 2016-2018 diperoleh dari hasil perhitungan pada data keuangan koperasi, disajikan dalam tabel berikut:

Tabel Rasio Kas Tahun 2016-2018

\begin{tabular}{|c|rr|rr|c|}
\hline Tahun & \multicolumn{2}{|c|}{ Kas + Bank } & \multicolumn{2}{|c|}{ Kewajiban Lancar } & \multicolumn{1}{c|}{ Rasio (\%) } \\
\hline 2016 & $\mathrm{Rp}$ & $135.227 .074,00$ & $\mathrm{Rp}$ & $9.510 .272 .768,00$ & 1,42 \\
\hline 2017 & $\mathrm{Rp}$ & $1.486 .511 .479,00$ & $\mathrm{Rp}$ & $7.554 .286 .526,00$ & 19,68 \\
\hline 2018 & $\mathrm{Rp}$ & $203.863 .445,00$ & $\mathrm{Rp}$ & $7.198 .253 .234,00$ & 2,83 \\
\hline
\end{tabular}

Sumber: Laporan Keuangan KSP-KU tahun 2016-2018 
Berdasarkan perhitungan rasio pada tabel, kemudian dilakukan penskoran untuk hasil rasio tersebut yang disajikan dalam tabel berikut ini:

Tabel Penskoran Rasio Kas Tahun 2016-2018

\begin{tabular}{|c|c|c|c|c|}
\hline Tahun & Rasio(\%) & Nilai (a) & Bobot (\%) (b) & Skor (a) $\mathbf{~}^{\star}(\mathbf{b})$ \\
\hline 2016 & 1,42 & 25 & 10 & 2,50 \\
\hline 2017 & 19,68 & 50 & 10 & 5,00 \\
\hline 2018 & 2,83 & 25 & 10 & 2,50 \\
\hline
\end{tabular}

Sumber: Data sekunder yang telah diolah

Berdasarkan perhitungan diatas, dapat diketahui bahwa rasio kas KSP-KU dari tahun 2016 sampai tahun 2017 mengalami kenaikan, dan dari tahun 2017 sampai tahun 2018 mengalami penurunan.

\section{$>\quad$ Kemandirian dan Pertumbuhan}

Penilaian aspek kemandirian dan pertumbuhan bertujuan untuk mengukur seberapa besar kemandirian dan pertumbuhan KSP-KU apabila dilihat dari kemampuannya memperoleh laba dan operasional pelayanannya.

1. Rasio Rentabilitas Aset

Rasio ini digunakan untuk mengetahui tingkat kemampuan KSP-KU dalam memperoleh SHU dengan memanfaatkan total aset yang dimilikinya. Rasio ini dihitung dengan rumus sebagai berikut:

Tahun 2016 $=\frac{R p 553.090 .220,00}{R p 18.616 .581 .687,00} \times 100 \%=2,97 \%$

$$
=\frac{\text { SHU sebelum pajak }}{\text { Total aset }} \times 100 \%
$$

Tahun 2017 $=\frac{R p 2.409 .772 .302,00}{R p 18.286 .996 .245,00} \times 100 \%=13,18 \%$

Tahun 2018 $=\frac{R p 2.763 .932 .882,00}{R p 16.150 .557 .577,00} \times 100 \%=17,11 \%$

Rasio rentabilitas aset KSP-KU tahun 2016-2018 diperoleh dari hasil perhitngan pada data keuangan koperasi, disajikan dalam tabel berikut ini:

Tabel Rasio Rentabilitas Aset Tahun 2016-2018

\begin{tabular}{|c|lc|lc|c|}
\hline Tahun & \multicolumn{2}{|c|}{ SHU Sebelum Pajak } & \multicolumn{2}{c|}{ Total Aset } & Rasio (\%) \\
\hline 2016 & $\mathrm{Rp}$ & 553.090 .220 & $\mathrm{Rp}$ & $18.616 .581 .687,00$ & 2,97 \\
\hline 2017 & $\mathrm{Rp}$ & 2.409 .772 .302 & $\mathrm{Rp}$ & $18.286 .996 .245,00$ & 13,18 \\
\hline 2018 & $\mathrm{Rp}$ & 2.763 .932 .882 & $\mathrm{Rp}$ & $16.150 .557 .577,00$ & 17,11 \\
\hline
\end{tabular}

Sumber: Laporan Keuangan KSP-KU tahun 2016-2018

Berdasarkan perhitungan rasio pada tabel, kemudian dilakukan penskoran untuk hasil rasio tersebut yang disajikan dalam tabel berikut ini:

Tabel Penskoran Rasio Rentabilitas Aset Tahun 2016-2018

\begin{tabular}{|c|c|c|c|c|}
\hline Tahun & Rasio(\%) & Nilai (a) & Bobot (\%) (b) & Skor (a) $^{\star}(\mathbf{b})$ \\
\hline 2016 & 2,97 & 25 & 3 & 0,75 \\
\hline 2017 & 13,18 & 100 & 3 & 3,00 \\
\hline 2018 & 17,11 & 100 & 3 & 3,00 \\
\hline
\end{tabular}

Sumber: Data sekunder yang telah diolah 
Berdasarkan perhitungan diatas, dapat diketahui bahwa rasio rentabilitas aset KSP-KU dari tahun 2016 sampai tahun 2017 mengalami kenaikan, dan dari tahun 2017 sampai tahun 2018 juga mengalami kenaikan.

\section{$>\quad$ Jatidiri Koperasi}

Penilaian aspek jatidiri koperasi bertujuan untuk mengukur keberhasilan koperasi dalam mencapai tujuannya yaitu mempromosikan ekonomi anggota.

1. Rasio Partisipasi Bruto

Rasio ini digunakan untuk mengetahui tingkat kemampuan KSP-KU dalam melayani anggota. Rasio ini dihitung dengan rumus sebagai berikut:

$$
=\frac{\text { Partisipasi Bruto }}{\text { Partisipasi Bruto }+ \text { Pendapatan }} \times 100 \%
$$

Tahun 2016 $=\frac{R p 3.106 .007 .200,00}{R p 3.235 .831 .216,00} \times 100 \%=95,99 \%$

Tahun 2017 $=\frac{R p ~ 4.577 .392 .800,00}{R p 4.821 .862 .627,00} \times 100 \%=94,93 \%$

Tahun 2018 $=\frac{\text { Thp } 4.369 .245 .000,00}{R p 4.675 .669 .904,00} \times 100 \%=93,45 \%$

Rasio partisipasi bruto KSP-KU tahun 2016-2018 diperoleh dari hasil perhitungan pada data keuangan koperasi, disajikan dalam tabel berikut:

Tabel Rasio Partisipasi Bruto Tahun 2016-2018

\begin{tabular}{|c|cc|cc|c|}
\hline Tahun & \multicolumn{2}{|c|}{ Partisipasi Bruto } & \multicolumn{2}{|c|}{$\begin{array}{c}\text { Partisipasi Bruto + } \\
\text { Pendapatan }\end{array}$} & $\begin{array}{c}\text { Rasio } \\
(\%)\end{array}$ \\
\hline 2016 & $\mathrm{Rp}$ & $3.106 .007 .200,00$ & $\mathrm{Rp}$ & 3.235 .831 .216 & 95,99 \\
\hline 2017 & $\mathrm{Rp}$ & $4.577 .392 .800,00$ & $\mathrm{Rp}$ & 4.821 .862 .627 & 94,93 \\
\hline 2018 & $\mathrm{Rp}$ & $4.369 .245 .000,00$ & $\mathrm{Rp}$ & 4.675 .669 .904 & 93,45 \\
\hline
\end{tabular}

Sumber: Laporan Keuangan KSP-KU tahun 2016-2018

Berdasarkan perhitungan rasio pada tabel, kemudian dilakukan penskoran untuk hasil rasio tersebut yang disajikan dalam tabel berikut ini:

Tabel Penskoran Rasio Partisipasi Bruto Tahun 2016-2018

\begin{tabular}{|c|c|c|c|c|}
\hline Tahun & Rasio(\%) & Nilai (a) & Bobot (\%) (b) & Skor (a) $^{\star}(\mathbf{b})$ \\
\hline 2016 & 95,99 & 100 & 7 & 7,00 \\
\hline 2017 & 94,93 & 100 & 7 & 7,00 \\
\hline 2018 & 93,45 & 100 & 7 & 7,00 \\
\hline
\end{tabular}

Sumber: Data sekunder yang telah diolah

Berdasarkan perhitungan diatas, dapat diketahui bahwa rasio partisipasi bruto KSP-KU dari tahun 2016 sampai tahun 2017 mengalami penurunan, dan dari tahun 2017 sampai tahun 2018 juga mengalami penurunan.

\section{b) Analisis Penetapan Kinerja Keuangan KSP-KU}

Berdasrkan hasil perhitungan sebelumnya, skor masing-masing rasio yang diperoleh kemudian digunakan sebagai dasar dalam penentuan kinerja keuangan KSP-KU. Adapun langkah selanjutnya dalam menentukan predikat kinerja keuangan KSP-KU tahun 2016 sampai dengan 2018 berdasarkan Peraturan Menteri Koperasi 
dan Usaha Kecil dan Menengah Republik Indonesia Nomor 06/Per/Dep.6/IV/2016 adalah sebagai berikut:

Menjumlahkan Skor Masing-masing Aspek Penilaian pada Tahun 2016-2018

Tabel Hasil Bobot Penilaian Aspek dan Komponen

\begin{tabular}{|c|c|c|c|c|c|}
\hline \multirow{2}{*}{ No. } & \multirow{2}{*}{ Aspek } & \multirow{2}{*}{ Komponen } & \multicolumn{3}{|c|}{ Bobot Penilaian } \\
\hline & & & 2016 & 2017 & 2018 \\
\hline \multirow[t]{2}{*}{1} & \multicolumn{2}{|c|}{ Permodalan } & 6 & 6 & 6 \\
\hline & & $\begin{array}{l}\text { a. Rasio Modal Sendiri } \\
\text { terhadap Total Aset }\end{array}$ & 6 & 6 & 6 \\
\hline \multirow[t]{3}{*}{2} & \multicolumn{2}{|c|}{ Efisiensi } & 6 & 6 & 6 \\
\hline & & $\begin{array}{l}\text { a. Rasio Beban Operasi } \\
\text { Anggota terhadap } \\
\text { Partisipasi Bruto }\end{array}$ & 4 & 4 & 4 \\
\hline & & \begin{tabular}{|ll} 
b. & Rasio \\
& Pelayanan
\end{tabular} & 2 & 2 & 2 \\
\hline \multirow[t]{2}{*}{3} & \multicolumn{2}{|c|}{ Likuiditas } & 2,5 & 5 & 2,5 \\
\hline & & a. Rasio Kas & 2,5 & 5 & 2,5 \\
\hline \multirow[t]{2}{*}{4} & \multicolumn{2}{|c|}{ Kemandirian dan Pertumbuhan } & 0,75 & 3 & 3 \\
\hline & & a. Rentabilitas Aset & 0,75 & 3 & 3 \\
\hline \multirow[t]{3}{*}{5} & \multicolumn{2}{|c|}{ Jatidiri Koperasi } & 7 & 7 & 7 \\
\hline & & a. Rasio Partisipasi Bruto & 7 & 7 & 7 \\
\hline & & Jumlah Skor & 22,25 & 27 & 24,50 \\
\hline
\end{tabular}

Sumber: Permen KUKM No.06/Per/Dep.6/IV/2016

$>\quad$ Penilaian Kesehatan Keuangan KSP-KU Untuk Setiap Aspek

Berdasarkan hasil perhitungan tabel 4.13 dapat pula diketahui tingkat kesehatan keuangan KSP-KU ditinjau dari masing-masing aspek keuangannya. Skor masing-masing aspek keuangan yang dihasilkan kemudian dibagi dengan skor maksimal yang dapat diperoleh dari setiap aspek keuangan tersebut, dan selanjutnya dikalikan skor maksimal ketujuh aspek yaitu 100 . Berikut ini merupakan hasil perhitungan dan predikat kinerja keuangan KSP-KU dari tahun 2016-2018 ditinjau dari masing-masing aspek.

1. Aspek Permodalan

Tabel Predikat Kinerja Keuangan KSP-KU Tahun 2016-2018 Ditinjau dari Aspek Permodalan

\begin{tabular}{|c|c|c|c|c|}
\hline Tahun & $\begin{array}{c}\text { Skor yang } \\
\text { dihasilkan } \\
\text { (a) }\end{array}$ & $\begin{array}{c}\text { Skor } \\
\text { Maksimal } \\
\text { (b) }\end{array}$ & $\frac{\boldsymbol{a}}{\boldsymbol{b}} \times \mathbf{1 0 0}$ & Predikat \\
\hline 2016 & 6 & 6 & 100 & Sehat \\
\hline 2017 & 6 & 6 & 100 & Sehat \\
\hline 2018 & 6 & 6 & 100 & Sehat \\
\hline
\end{tabular}

Sumber: Data sekunder yang telah diolah 
2. Aspek Efisiensi

Tabel Predikat Kinerja Keuangan KSP-KU Tahun 2016-2018 Ditinjau dari Aspek Efisiensi

\begin{tabular}{|c|c|c|c|c|}
\hline Tahun & $\begin{array}{c}\text { Skor yang } \\
\text { dihasilkan } \\
\text { (a) }\end{array}$ & $\begin{array}{c}\text { Skor } \\
\text { Maksimal } \\
\text { (b) }\end{array}$ & $\frac{\boldsymbol{a}}{\boldsymbol{b}} \times \mathbf{1 0 0}$ & Predikat \\
\hline 2016 & 6 & 6 & 100 & Sehat \\
\hline 2017 & 6 & 6 & 100 & Sehat \\
\hline 2018 & 6 & 6 & 100 & Sehat \\
\hline
\end{tabular}

Sumber: Data sekunder yang telah diolah

3. Aspek Likuiditas

Tabel Predikat Kinerja Keuangan KSP-KU Tahun 2016-2018 Ditinjau dari Aspek Likuiditas

\begin{tabular}{|c|c|c|c|c|}
\hline Tahun & $\begin{array}{c}\text { Skor yang } \\
\text { dihasilkan } \\
\text { (a) }\end{array}$ & $\begin{array}{c}\text { Skor } \\
\text { Maksimal } \\
\text { (b) }\end{array}$ & $\frac{a}{b} \times 100$ & Predikat \\
\hline 2016 & 2,5 & 10 & 25 & $\begin{array}{c}\text { Dalam Pengawasan } \\
\text { Khusus }\end{array}$ \\
\hline 2017 & 5 & 10 & 50 & $\begin{array}{c}\text { Dalam Pengawasan } \\
\text { Khusus }\end{array}$ \\
\hline 2018 & 2,5 & 10 & 25 & $\begin{array}{c}\text { Dalam Pengawasan } \\
\text { Khusus }\end{array}$ \\
\hline
\end{tabular}

Sumber: Data sekunder yang telah diolah

4. Aspek Kemandirian dan Pertumbuhan

Tabel Predikat Kinerja Keuangan KSP-KU Tahun 2016-2018 Ditinjau dari Aspek Kemandirian dan Pertumbuhan

\begin{tabular}{|c|c|c|c|c|}
\hline Tahun & $\begin{array}{c}\text { Skor yang } \\
\text { dihasilkan } \\
\text { (a) }\end{array}$ & $\begin{array}{c}\text { Skor } \\
\text { Maksimal } \\
\text { (b) }\end{array}$ & $\frac{\boldsymbol{a}}{\boldsymbol{b}} \times \mathbf{1 0 0}$ & Predikat \\
\hline 2016 & 0,75 & 3 & 25 & $\begin{array}{c}\text { Dalam Pengawasan } \\
\text { Khusus }\end{array}$ \\
\hline 2017 & 3 & 3 & 100 & Sehat \\
\hline 2018 & 3 & 3 & 100 & Sehat \\
\hline
\end{tabular}

Sumber: Data sekunder yang telah diolah

5. Aspek Jatidiri Koperasi

Tabel Predikat Kinerja Keuangan KSP-KU Tahun 2016-2018 Ditinjau dari Aspek Jatidiri Koperasi

\begin{tabular}{|c|c|c|c|c|}
\hline Tahun & $\begin{array}{c}\text { Skor yang } \\
\text { dihasilkan } \\
\text { (a) }\end{array}$ & $\begin{array}{c}\text { Skor } \\
\text { Maksimal } \\
\text { (b) }\end{array}$ & $\frac{\boldsymbol{a}}{\boldsymbol{b}} \times \mathbf{1 0 0}$ & Predikat \\
\hline 2016 & 7 & 7 & 100 & Sehat \\
\hline 2017 & 7 & 7 & 100 & Sehat \\
\hline 2018 & 7 & 7 & 100 & Sehat \\
\hline
\end{tabular}

Sumber: Data sekunder yang telah diolah 


\section{E. PEMBAHASAN}

\section{1) Aspek Permodalan}

Aspek permodalan dinilai untuk mengetahui informasi mengenai kecukupan modal KSP-KU dalam mendukung kegiatan operasionalnya. Berikut ini merupakan penjelasan terkait dengan rasio-rasio aspek permodalan berdasarkan hasil penilaian kinerja keuangan KSP-KU tahun 2016-2018:

$>$ Rasio Modal Sendiri terhadap Total Aset

Rasio ini digunakan untuk mengetahui tingkat kemampuan modal sendiri KSP$\mathrm{KU}$ dalam mendukung pendanaan terhadap total aset yang dimilikinya. Berdasarkan tabel 4.2, pada tahun 2016 rasio yang diperoleh sebesar 48,92\% sehingga mendapat nilai 100 dengan skor 6,00. Tahun 2017 rasio yang diperoleh sebesar 58,69\% sehingga mendapat nilai 100 dengan skor 6,00. Tahun 2018 rasio yang diperoleh sebesar 55,43\% sehingga mendapat nilai 100 dengan skor 6,00.

Rasio Rata-rata yang diperoleh sebesar 54,35\% dengan skor 6,00 dan merupakan skor maksimal. Hal ini berarti modal sendiri KSP-KU memiliki kualitas yang sangat baik dalam mendukung pendanaan terhadap total aset yang dimilikinya. Dengan demikian, diharapkan KSP-KU dapat mempertahankan kondisi ini.

\section{2) Aspek Efisiensi}

Penilaian aspek efisiensi bertujuan untuk mengukur tingkat kemampuan KSP-

$\mathrm{KU}$ dalam memberikan pelayanan kepada anggotanya dengan aset yang dimilikinya. Berikut ini merupakan penjelasan terkait dengan rasio-rasio aspek efisiensi berdasarkan hasil penelitian kinerja keuangan KSP-KU tahun 2016-2018:

a. Rasio Beban Operasi Anggota terhadap Partisipasi Bruto

Rasio ini digunakan untuk mengetahui kemampuan partisipasi bruto KSP-KU dalam menutup kemungkinan kerugian akibat besarnya beban operasi anggota. Dalam hal ini, beban operasi anggota merupakan jumlah keseluruhan beban KSP-KU yang terdiri dari beban bunga, beban perkoperasian, beban manajemen dan beban administrasi. Partisipasi bruto merupakan pendapatan KSP-KU dari jasa simpan pinjam. Berdasarkan tabel 4.4, pada tahun 2016 rasio yang diperoleh sebesar $86,36 \%$ sehingga mendapat nilai 100 dengan skor 4,00. Tahun 2017 rasio yang diperoleh sebesar $51,70 \%$ sehingga mendapat nilai 100 dengan skor 4,00. Tahun 2018 rasio diperoleh sebesar 43,60\% sehingga mendapat nilai 100 dengan skor 4,00.

Rasio rata-rata diperoleh sebesar 60,55 dengan skor 4,00 dan merupakan skor maksimal. Hal ini berarti KSP-KU telah memberikan efisiensi pelayanan kepada para anggotanya dengan penggunaan aset yang dimiliki. Partisipasi bruto yang tinggi menunjukkan bahwa kontribusi anggota terhadap koperasi juga tinggi dan meningkatkan perolehan SHU. Diharapkan KSP-KU mempertahankan atau bahkan meningkatkannya untuk tahun berikutnya.

b. Rasio Efisiensi Pelayanan

Rasio ini digunakan untuk mengetahui tingkat kemampuan volume pinjama yang diberikan KSP-KU dalam menutup kemungkinan kerugian akibat besarnya beban karyawan koperasi. Berdasarkan tabel 4.6, pada tahun 2016 rasio yang diperoleh sebesar $0,94 \%$ sehingga mendapat nilai 100 dengan skor 2,00. Tahun 2017 rasio diperoleh sebesar 1,25\% sehingga mendapat nilai 100 
dengan skor 2,00. Tahun 2018 rasio diperoleh sebesar 1,37\% sehingga mendapat nilai 100 dengan skor 2,00.

Rasio rata-rata diperoleh sebesar $1,18 \%$ dengan skor 2,00 dan merupakan skor maksimal. Semakin rendah rasio yang dihasilkan, maka semakin tinggi skor yang diperoleh. Hal ini berarti nahwa KSP-KU tergolong sangat baik dalam efisiensi pelayanan. Karyawan KSP-KU harus mempertahankan efisiensi pelayanannya kepada anggota agar perolehan SHU dapat maksimal.

\section{3) Aspek Likuiditas}

Penilaian aspek likuiditas bertujuan untuk mengukur tingkat kemampuan KSP-

$\mathrm{KU}$ dalam memenuhi kewajiban jangka pendeknya. Berikut ini merupakan penjelasan terkait dengan rasio-rasio aspek likuiditas berdasarkan hasil penilaian kinerja keuangan KSP-KU tahun 2016-2018:

$>$ Rasio Kas

Rasio ini digunakan untuk mengetahui tingkat kemampuan KSP-KU dalam membayar hutang jangka pendeknya dengan menggunakan kas dan bank yang dimiliki koperasi. Berdasarkan tabel 4.8, pada tahun 2016 rasio diperoleh sebesar 1,42\% sehingga mendapat nilai 25 dengan skor 2,50. Tahun 2017 rasio diperoleh sebesar $19,68 \%$ sehingga mendapat nilai 50 dengan skor 5,00. Tahun 2018 rasio diperoleh sebesar 2,83\% sehingga mendapat nilai 25 dengan skor 2,50 .

Rasio rata-rata diperoleh sebesar 7,97\% dengan skor 2,50 dan merupakan skor terendah, padahal dalam peraturan penskoran, skor maksimal yang ada sebesar 10. Skor maksimal diperoleh ketika rasio kas berada pada 10-15\%. Hal ini berarti bahwa rasio kas masih buruk. Pada KSP-KU perbandingan antara bank dan kas dengan kewajiban lancar sangatlah tidak seimbang. Dengan demikian dapat dikatakan bahwa terdapat banyak dana yang menganggur sehingga kondisi KSP-KU ada pada over likuid. KSP-KU sebaiknya menyeimbangkan kas dan bank dengan kewajiban lancarnya. Nilai kas dan bank dapat diperkecil dengan cara menyalurkan dana tersebut ke nasabah dalam bentuk pinjaman, sedangkan kewajiban lancar dapat ditingkatkan dengan cara menarik nasabah untuk menabung di KSP-KU.

\section{4) Aspek Kemandirian dan Pertumbuhan}

Penilaian aspek ini bertujuan untuk mengukur seberapa besar kemandirian dan pertumbuhan KSP-KU apabila dilihat dari kemampuannya memperoleh laba dan operasional pelayanannya. Berikut ini merupakan penjelasan terkait dengan rasiorasio aspek kemandirian dan pertumbuhan berdasarkan hasil penilaian kinerja keuangan KSP-KU tahun 2016-2018:

Rasio Rentabilitas Aset

Rasio ini digunakan untuk mengetahui tingkat kemampuan KSP-KU dalam memperoleh SHU dengan memanfaatkan total aset yang dimilikinya. Berdasarkan tabel 4.10, pada tahun 2016 rasio diperoleh sebesar 2,97\% sehingga mendapat nilai 25 dengan skor 0,75. Tahun 2017 rasio diperoleh sebesar 13,18\% sehingga mendapat nilai 100 dengan skor 3,00. Tahun 2018 rasio diperoleh sebesar $17,11 \%$ sehingga mendapat nilai 100 dengan skor 3,00. Rasio rata-rata $11,09 \%$ dengan skor 3,00 dan merupakan skor maksimal. Semakin tinggi rasio yang diperoleh, maka semakin tinggi tingkat rentabilitasnya. Hal ini berarti rentabilitas aset KSP-KU sangat baik. KSP-KU 
diharapkan dapat mempertahankan dan bahkan meningkatkannya ditahun berikutnya.

\section{5) Aspek Jatidiri Koperasi}

Rasio ini digunakan untuk mengetahui tingkat kemampuan KSP-KU dalam melayani anggotanya, semakin tinggi persentasenya maka akan semakin baik. Berikut ini merupakan penjelasan terkait dengan rasio-rasio aspek jatidiri koperasi berdasarkan hasil penilaian kinerja keuangan KSP-KU tahun 2016-2018:

> Rasio Partisipasi Bruto

Berdasarkan tabel, pada tahun 2016 rasio diperoleh sebesar 95,99\% sehingga mendapat nilai 100 dengan skor 7,00. Tahun 2017 rasio diperoleh sebesar $94,93 \%$ sehingga mendapat nilai 100 dengan nilai 7,00. Tahun 2018 rasio diperoleh sebesar 93,45\% sehingga mendapat nilai 100 dengan nilai 7,00.

Rasio rata-rata $94,78 \%$ dengan skor 7,00 dan merupakan skor maksimal. Hal ini berarti bahwa partisipasi bruto pada KSP-KU memiliki kondisi sangat baik. Diharapkan KSP-KU dapat mempertahankan kondisi ini.

\section{6) Penilaian Kesehatan Koperasi Secara Keseluruhan}

Berdasarkan Peraturan Menteri Koperasi dan Usaha Kecil dan Menengah Republik Indonesia Nomor 06/Per/Dep.6/IV/2016 terdapat tujuh aspek yang dinilai meliputi aspek permodalan, kualitas aktiva produktif, manajemen, efisiensi, likuiditas, kemandirian dan pertumbuhan, serta jatidiri koperasi dengan skor maksimal 100 . Dalam hal ini, peneliti hanya menggunakan aspek permodalan, efisiensi, likuiditas, kemandirian dan pertumbuhan, serta jatidiri koperasi dalam menilai kinerja keuangan KSP-KU dengan skor maksimal 32.

Berdasarkan tabel diatas, jumlah skor yang diperoleh pada tahun 2016, 2017 dan 2018 kemudian dibagi dengan 32 dan selanjutnya dikalikan dengan 100 (skor maksimal tujuh aspek). Perhitungan dan predikat kinerja keuangan KSP-KU dari tahun 2016 sampai dengan 2018 dapat dilihat pada tabel berikut ini:

Tabel Predikat Kinerja Keuangan KSP-KU Tahun 2016-2018

\begin{tabular}{|c|l|c|c|}
\hline Tahun & \multicolumn{1}{|c|}{ Perhitungan } & Skor & Predikat \\
\hline 2016 & $22,25 / 32 \times 100$ & 69,53 & Cukup Sehat \\
\hline 2017 & $27 / 32 \times 100$ & 84,38 & Sehat \\
\hline 2018 & $24,50 / 32 \times 100$ & 76,56 & Cukup Sehat \\
\hline
\end{tabular}

Sumber: Permen KUKM No.06/Per/Dep.6/IV/2016

Hasil penilaian terhadap kesehatan KSP-KU pada tahun 2016 memperoleh nilai 69,53 dengan predikat koperasi cukup sehat. Tahun 2017 nilai naik menjadi 84,38 dengan predikat koperasi sehat. Selanjutnya pada tahun 2018 nilai turun menjadi 76,56 dengan predikat koperasi cukup sehat. Dengan demikian dapat dikatakan bahwa tingkat kesehatan KSP-KU dari tahun 2016-2018 berada pada kondisi koperasi cukup sehat.

\section{F. KESIMPULAN}

Berdasarkan pengolahan data keuangan yang telah dilakukan, maka dapat diambil kesimpulan bahwa tingkat kesehatan KSP-KU Periode 2016-2018 adalah sebagai berikut: 
1. Ditinjau dari aspek permodalan, kualitas permodalan KSP-KU periode 2016-2018 mempunyai rerata skor 6,00 dimana skor maksimalnya adalah 6, dikategorikan dengan predikat sehat.

2. Ditinjau dari aspek efisiensi, kualitas efisiensi KSP-KU periode 2016-2018 mempunyai rerata skor 6,00 dimana skor maksimalnya adalah 6 , dikategorikan dengan predikat sehat.

3. Ditinjau dari aspek likuiditas, kualitas likuiditas KSP-KU periode 2016-2018 mempunyai skor rata-rata 3,32 dimana skor maksimalnya sebesar 10 . Skor tersebut berada pada rasio $<51,00$, sehingga dikategorikan dengan predikat dalam pengawasan khusus.

4. Ditinjau dari aspek kemandirian dan pertumbuhan, kualitas kemandirian dan pertumbuhan KSP-KU periode 2016-2018 mempunyai rerata skor 2,25 dimana skor maksimalnya adalah 3. Skor tersebut berada pada rasio berkisar 66,00 80,00 , sehingga dikategorikan dengan preedikat cukup sehat.

5. Ditinjau dari aspek jatidiri, kualitas jatidiri KSP-KU periode 2016-2018 memperoleh rerata skor sebesar 7,00 dimana skor maksimalnya adalah 7, dikategorikan dengan predikat sehat.

6. Hasil penilaian terhadap tingkat kesehatan KSP-KU pada tahun 2016-2018 memperoleh rerata skor sebesar 76,82 dapat dikategorikan dengan predikat cukup sehat.

\section{G. SARAN}

Berdasarkan kesimpulan yang telah didapatkan dari hasil analisis tingkat kesehatan KSP-KU periode 2016-2018, maka saran yang dapat disampaikan adalah sebagai berikut:

1. Mengingat kualitas permodalan KSP-KU periode $2016-2018$ berada pada kategori sehat, maka pengelola KSP-KU diharapkan dapat mempertahankan kualitas permodalan yang sudah baik.

2. Mengingat kualitas efisiensi KSP-KU periode $2016-2018$ berada pada kategori sehat, maka pengelola KSP-KU diharapkan dapat mempertahankan kualitas efisiensi yang sudah baik.

3. Mengingat kualitas likuiditas yang dimiliki KSP-KU periode $2016-2018$ berada pada kategori dalam pengawasan khusus, diharapkan pengelola KSP-KU dapat melakukan perbaikan dalam pengelolaan rasio kas yang masih buruk. Pada KSP-KU perbandingan antara kas dan bank dengan kewajiban lancar sangatlah tidak seimbang. Dengan demikian dapat dikatakan bahwa terdapat banyak dana yang menganggur sehingga kondisi KSP-KU ada pada over likuid. KSP-KU sebaiknya menyeimbangkan kas dan bank dengan kewajiban lancarnya. Nilai kas dan bank dapat diperkecil dengan cara menyalurkan dana tersebut ke nasabah dalam bentuk pinjaman, sedangkan kewajiban lancar dapat ditingkatkan dengan cara menarik nasabah untuk menabung di KSP-KU.

4. Mengingat kualitas kemandirian dan pertumbuhan yang dimiliki KSP-KU periode 2016-2018 berada pada kategori cukup sehat, pengelola KSP-KU diharapkan mampu mempertahankan kemandirian operasional pelayanan yang sudah baik dan diharapkan mampu meningkatkan perolehan SHU sebelum pajak dengan memaksimalkan pendapatan melalui partisipasi anggota dalam kegiatan simpan pinjam. 
5. Mengingat kualitas jatidiri yang dimiliki KSP-KU periode 2016-2018 berada pada kategori sehat, maka pengelola KSP-KU diharapkan mampu mempertahankan kondisi ini.

6. Mengingat tingkat kesehatan KSP selama 3 tahun hanya berada dalam kategori cukup sehat dan belum mencapai kategori sehat, yang disebabkan oleh rendahnya aspek likuiditas dan aspek kemandirian dan pertumbuhan maka sangat diperlukan perbaikan untuk aspek-aspek tersebut agar dapat memperoleh kualitas yang baik. Aspek-aspek yang sudah baik dan dikategorikan sehat seperti aspek permodalan, aspek efisiensi dan aspek jatidiri koperasi agar pihak koperasi sebaiknya dapat mempertahankan kondisi ini.

\section{DAFTAR PUSTAKA}

Apriadi, Andi. 2014. Analisis Kinerja Keuangan Koperasi berdasarkan Peraturan Menteri Negara Koperasi dan Usaha Kecil dan Menengah Republik Indonesia Nomor 14/Per/M.KUKM/XII/2009. Skripsi. Fakultas Keguruan dan IImu Pendidikan Universitas Sanata Dharma Yogyakarta.

Aryani, Sri. 2014. Analisis Kinerja Keuangan Pada Koperasi Pegawai Mufakat Pangkalan Balai Kabupaten Banyuasin. Skripsi. Fakultas Ekonomi Universitas PGRI Palembang.

Fahmi, Irham. 2011. Analisis Kinerja Keuangan. Bandung: Alfabeta.

Kasmir. 2012. Analisis Laporan Keuangan. Jakarta: PT Raja Grafindo Persada.

Munawir. 2010. Analisis Laporan Keuangan. Yogyakarta: Liberty.

Nugroho, Oktavian. 2015. Analisis Kinerja Keuangan Koperasi pada Koperasi Beringin Palembang. Skripsi. Fakultas Ekonomi Universitas PGRIPalembang.

Peraturan Menteri Negara Koperasi dan UKM Nomor 21/Per/M.KUKM/XI/2008 tentang Pedoman Pengawasan Koperasi Simpan Pinjam dan Unit Simpan Pinjam Koperasi.

Peraturan Menteri Negara Koperasi dan Usaha Kecil dan Menengah Republik Indonesia No. 14/Per/M.KUKM/XII/2009 tentang Perubahan atas Peraturan Menteri Negara Koperasi dan Usaha Kecil dan Menengah No. 20/Per/M.KUKM/XI/2008 tentang Pedoman Penilaian Kesehatan Koperasi Simpan Pinjam dan Unit Simpan Pinjam Koperasi.

Peraturan Menteri Koperasi dan Usaha Kecil dan Menengah Republik Indonesia Nomor 06/Per/Dep.6/IV/2016 tentang Pedoman Penilaian Kesehatan Koperasi Simpan Pinjam dan Unit Simpan Pinjam Koperasi

Sugiyono. 2018. Metode Penelitian. Bandung: Alfabeta. 
Tyas, Alfi Rohmaning. 2014. Analisis Tingkat Kesehatan Koperasi Simpan Pinjam Mukti Bina Usaha Kelurahan Muktisari Kota Banjar Jawa Barat Tahun 20112013. Skripsi. Fakultas Ekonomi Universitas Negeri Yogyakarta.

Undang - Undang No.25 tahun 1992 Tentang Perkoperasian 